\title{
歪みセンサのフィードフォワードに基づく 磁気軸受活用の制振*
}

\author{
涌井伸二品 後藤勇 人 $^{* * *}$
}

Key words: magnetic bearing, turbo molecular pump, anti-vibration, strain sensor

\section{1. 緒言}

磁気軸受を使った真空機器としてのターボ分子ポンプ (以下, TMP と略記）を制振装置として活用する研究を行なっている. 具体的に，文献 1)では，両端クランプした梁中央に TPM を賏架 し，この近傍に設置した加速度センサに基づく TMP 内のロータ の強制加振により梁のベンディング振動を抑制した.

本寄書では，振動検出センサとして，加速度センサに代えて 装着スペースに制約のない歪みセンサを用いる，あわせて，磁 気軸受のフィードバック（以下，FB と略記）系を制振向けとす るために, 従来の PD 制御, 磁束 FB 付き PD 制御, そして磁束 と変位の掛算 $\mathrm{FB}$ 付き $\mathrm{PD}$ 制御の 3 種類で比較した. この結果を 報告する.

\section{TMP を用いた制振実験の構成}

\section{1 装置構成}

図 1 に磁気軸受内蔵の TMP(EXT 250M/100CF)を使った制振実 験の構成を示す．同軸受は永久磁石を併用した磁場変調形であ り，鉛直方向だけを能動的に制御する，半径方向は，受動的な 復元力を活用している.制振対象は，両端クランプした $\mathrm{Al}$ 製の 梁であり, 長さ $1,250 \times$ 幅 $158 \times$ 高さ $26 \mathrm{~mm}$ のサイズである. 汎 用の箔歪みセンサ（KFG-1-120-C1-23 L3M2R）を両端クランプ した梁中央の上下面に貼り付けた.いわゆる, 2 ゲージ法であり, 梁の曲げを検出する. TMP は梁中央にボルトでクランプされる. このロータを, 歪みセンサの出力に基づきフィードフォワード

(以下, FF と略記) 駆動し,この駆動反力で梁の 1 次ベンディ ング振動を抑制する．制振効果を評価するために，歪みセンサ の直近にはサーボ形加速度センサ（JA-5V）を装着した。

\section{2 歪みセンサの活用理由}

露光装置では, 材料を䩦選し, かつ固有值計算を踏まえて設 計・製造にもかかわらず, 露光精度向上を阻害する構造体の弾 性振動に起因した課題がある.そこで, 構造体に歪みセンサを 貼付して振動の様子を把握し，この知見を踏まえて構造体設計 の指針にすることがある. より進展させて，文献 2)では，歪み センサの出力に基づいて露光誤差を補正する提案がなされてい る.このように, 露光装置の構造体の振動検出のために, 歪み センサを適用する開発の土壌は既にある. 加えて, 露光装置の ような大型構造体でも, 装着スペースには制約があるため, 加 速度センサよりも歪みセンサの使用の方が適すると考えられる.

\section{3. 梁の制振実験}

\section{1 FF 補償器}

文献 1)では, 梁に取り付けた加速度センサの 1 階積分の信号

* 原稿受付 平成 21 年 3 月 10 日

** 正会員 東京農工大学大学院（東京都小金井市中町 2-24-16）

*** 東京農工大学大学院電気電子工学専攻
を磁気軸受の電流ドライバ前段に FF した. すなわち, 梁の速度 に比例した駆動力を発生させてダンピングを掛けた。これに対 して, 歪みセンサの出力を用いる FF の場合, この出力は変位に 相当するので， 1 階微分の信号を電流ドライバ前段に FF せねば ならない, そのため, 図 1 を参照して, 歪みセンサの出力後段 の Vel. FF には擬似微分補償器を実装した. この折点周波数は $300 \mathrm{~Hz}$ であり, 高周波ノイズ除去のため同一の折点周波数を持 つ2次ローパスフィルタも実装した. そして, Vel. FF 後段に FF の調整ゲイン $K_{V}$ を設けた。

\section{2 FB 系の改良}

市販の TMPにお泣磁気軸受は, 安定浮上の機能だけを実現 する定置制御系である. 本寄書のように, FB 系内への FF 信号 導入は前提としていない，具体的に，ほとんどの市販品は，閉 ループ系の共振を積極的に抑えていない，加えて，定常位置偏 差零の実現もはかっていない，前者の理由は，この共振周波数 をはるかに超えたところが定格回転数となるため, 共振点通過 の際にロータが不安定化, あるいは振机回りの増大によってス テータ側と機械接触しない限り，定格の高速回転下では，振れ 回り小の状態が慣性中心で実現されるからである. 一方, 後者 の定常偏差を許す理由は, 安定なロー夕の回転中心は, 磁気軸 受に内蔵する位置センサの平衡位置ではないからである。すな わち, 定常位置偏差零による過剩なロータの位置拘束は安定回 転の妨げになるためと考えられる，ここで，共振の放置は，磁 気軸受を制振用途に適用しようと寸る本寄書の立場では障害と なる，そこで，制振向けに FB 系を改良する．ここでは，磁束 $\mathrm{FB}$ (以下， $\phi \mathrm{FB}$ と略記）と, これに加えて磁束と位置の掛算 $\mathrm{FB}$ (以下， $\phi \mathrm{FB}+\phi \cdot x \mathrm{FB}$ と略記）を付加した 2 種類を導入し た.この中の $\phi \mathrm{FB}$ は磁気軸受の負剛性を最小化する機能がある ことは既に知られている. そこで, 新規と考えられる $\phi \mathrm{FB}+\phi ・$ $x \mathrm{FB}$ を導入する. この説明のために, 以降に数式モデルを示す.

永久磁石を併用する磁場変調形の磁気軸受の数式モデルは文 献 3)を参照して以下の通りである.

$$
\phi=-\frac{N R}{c_{1}}\left(c_{2}-x\right) \cdot \phi(x)+e
$$

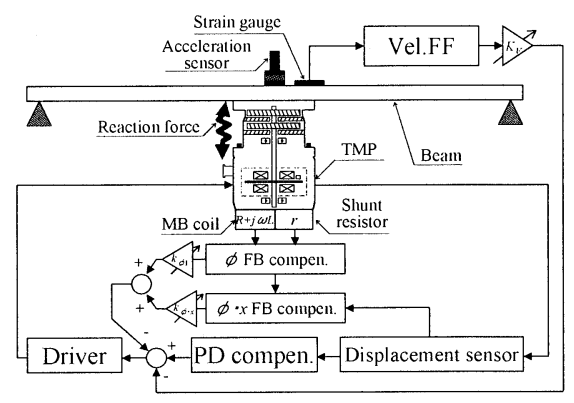

Fig.1 Experimental setup for an anti-vibration using TMP 


$$
\begin{aligned}
& f_{m}=\frac{N^{2}}{2 c_{1}} \phi(x)^{2} \\
& m \ddot{x}=f_{m}-m g-f_{d} \\
& \phi(x)=\frac{\mu_{0} S\left(N i+l_{p} H_{c}\right)}{\frac{l_{i}}{\mu_{s}}+\frac{\mu_{0} l_{p} H_{c}}{B_{r}}-2 x} \\
& c_{1}=\frac{N^{2} \mu_{0} S}{2}, \quad c_{2}=\frac{l_{i}}{2 \mu_{s}}+\frac{\mu_{0} l_{p} H_{c}}{2 B_{r}}
\end{aligned}
$$

ただし, $x$ : ロータの変位, $i:$ コイル電流, $f_{m}$ : 磁気吸引力, $f_{d}$ : 外乱, $\phi$ : 磁束, $\mu_{0}$ : 真空の透磁率, $\mu_{s}$ : 鉄心の比透磁率, $S$ : 鉄心の断面積, $N$ : コイル巻数, $R:$ コイル抵抗, $m:$ ロータの 質量, $B_{r}$ : 残留磁束密度, $H_{c}$ : 保持力, $l_{i}$ : 磁路の長さ, $l_{p}$ : 永 久磁石の磁路の長さ，である.

ここで, 式(1)の右辺より, 磁束 $\phi$ のループとともに, 磁束 $\phi$ と 変位 $x$ の掛算の両ループが存在することがわかる. そこで，よく 知られている $\phi \mathrm{FB}$ に加え, さらに磁束 $\phi$ と位置 $x$ の掛算のルー プ構造をキャンセルする FBを新規に付加する.この $\phi \mathrm{FB}+\phi ・ x \mathrm{FB}$ の導入により閉ループ系の特性改善が図れれば，制振性能の向上 が期待できる.この考えに基づいて構成した FB 制御系は図 2 で ある. コイル両端電圧 $e_{v}$ とコイル電流 $i$ の電圧検出值を $e_{i}$ とおき, $\int\left\{k_{v} e_{v}-k_{i} \cdot(R / r) e_{i}\right\} d t$ の演算(実装は折点 $0.5 \mathrm{~Hz}$ の擬似積分器)によ って磁束が推定される. ただし, $r$ はコイルの電流検出抵抗であ る. 残存する直流成分を除去するために折点 $0.5 \mathrm{~Hz}$ の直流カット フィルタを通し，さらにゲイン $k_{\phi 1}$ で $\phi \mathrm{FB}$ が調整される. 一方, ゲイン $k_{\phi 2}$ と $k_{x}$ を通った信号を掛算器に導いて, 磁束 $\phi$ と位置 $x$ の掛算信号が生成され，ゲイン $k_{\phi} \cdot x$ でこの FB 調整がなされる.

\section{3 制振実験}

歪みセンサの出力に基づく FFによって, 図 1 に示す梁の 1 次 ベンディングを制振する．まず，周波数応答分析装置の正弦波 信号を磁気軸受のドライバ前段に加算し，この信号から評価用 の加速度センサ出力までのイナータンス応答を取得した．図 3 上段は，FB 系の種類によるイナータンス応答の差異である．い ずれの FB 制御系でも，調整ゲイン $K_{V}$ の増大にしたがって共振 ピークの抑制がはかれる．注目することは，イナータンス応答 高域の平坦性が, $\mathrm{PD}, \mathrm{PD}+\phi \mathrm{FB}$, そして $\mathrm{PD}+\phi \mathrm{FB}+\phi \cdot x \mathrm{FB}$ の 順番に回復されていることである. 次に, 図 3 中段は FF オフの ときにあって, 梁中央部を打撃したときの評価用の加速度セン サの出力を示す．この減衰の長い振動は， $K_{V}$ 投入により図 3 下 段に示すように，ダンピング付与によって収束を速めている. ただし, 正弦波加振の場合には $K_{V}=800$ まで安定にデータを取得 できたが，梁の打撃試験の場合には，PD と $\mathrm{PD}+\phi \mathrm{FB}$ 制御とも

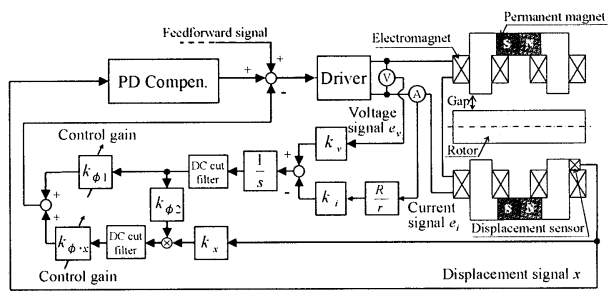

Fig.2 Feedback control scheme including minor loops

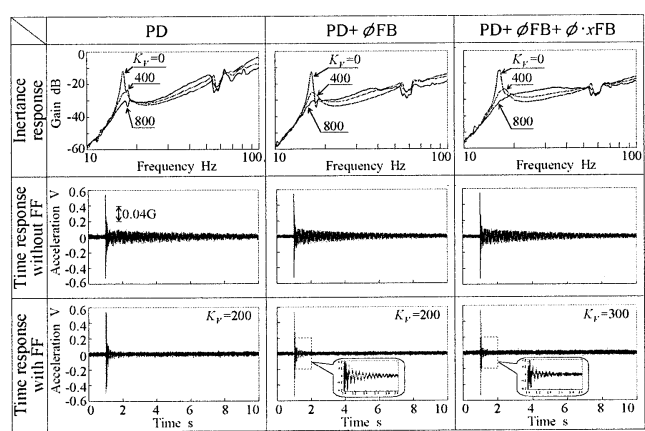

Fig.3 Experimental results showing anti-vibration

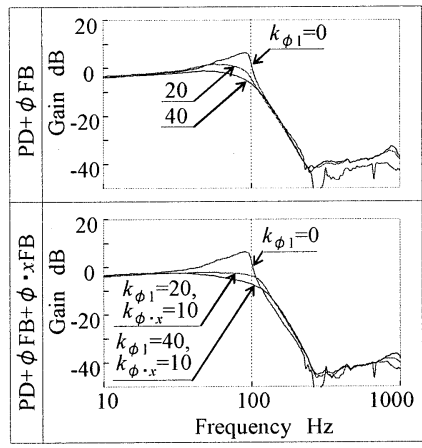

Fig.4 Closed frequency responses without and with $\phi \cdot x \mathrm{FB}$

に $K_{V}=200$ までしか投入できない. $K_{V}=300$ のときには発振した. しかし, 図 3 右側の $\mathrm{PD}+\phi \mathrm{FB}+\phi \cdot x \mathrm{FB}$ の場合には $K_{V}=300$ まで 投入でき, したがってロータを FF 駆動により大スイングさせて も不安定化することなく，同図右側および中央に比較して制振 効果をあげることができている，この理由と考えられるロータ 大スイング（ $300 \mu \mathrm{m}$ ギャップに対して p-p 值で $18 \mu \mathrm{m} ）$ 時の磁気 軸受の閉ループ周波数特性を図 4 に示す. 同図上下段の比較よ り, $k_{0} \cdot x$ の投入により, 周波数特性の平坦性確保と帯域拡大が 確認できる. 図示しないが, p-p 值で $1.8 \mu \mathrm{m}$ の小スイングで閉ル 一プ周波数応答を測定した結果も同様であり，特に共振を抑え る効果がある. なお， $K_{V}$ のほかに, 歪センサの出力を直接に FF して梁の 1 次固有周波数を高域へ，あるいは同センサ出力に 2 階の微分演算を施した信号を FFして 1 次固有振動数を低域へと シフトさせる調整も行えている，さらに，梁の曲げ歪み検出に 代えて，梁の側面に歪みセンサを貼付した引張り・圧縮歪み検 出に基づく FFでも図 3 下段と同様に機能することを確認してい る.

\section{4. 結言}

磁気軸受内蔵のTMP 制振装置としても活用することを狙い として，制振対象の梁に貼付した歪みセンサの出力に基づく FF 駆動によって，梁の 1 次ベンディングを制振した。この際，磁 束と変位の掛算 $\mathrm{FB}$ を磁気軸受の閉ループ系に導入して, 制振効 果を増進することができた。

\section{参 考 文 献}

1）涌井伸二，田中寿也，赤津観：磁気軸受を用いたターボ分子ポンプ の制振装置一の応用, 精密工学会誌, 71, 9(2005)1184.

2) ニコン: : 露光方法及び露光装置, 特開 2000-269118(2000).

3）日本機械学会編：磁気軸受の基礎と応用，養賢堂(1995)25. 